\title{
KOMPOSISI JENIS DAN DISTRIBUSI IKAN PETEK (LEIOGNATHIDAE) DI PERAIRAN SELAT MAKASSAR
}

\author{
Wedjatmiko"), Tri Ernawati'1), dan Sukarniaty²) \\ 1) Peneliti pada Balai Riset Perikanan Laut, Muara Baru-Jakarta \\ 2) Teknisi Litkayasa pada Balai Riset Perikanan Laut, Muara Baru-Jakarta
}

\begin{abstract}
ABSTRAK
Penelitian terhadap komposisi dan distribusi ikan petek (Leiognathidae) di perairan Selat Makassar (perairan timur Kalimantan), dilakukan pada bulan Juni sampai dengan Juli 2005 dengan menggunakan KM. Bawal Putih. Hasil penelitian menunjukkan bahwa hasil tangkapan ikan petek (Leiognathidae) merupakan ikan dominan yang ke-2 dengan persentase 17,43\%. Pada penelitian ini diperoleh 12 jenis ikan petek (Leiognathidae), dengan 3 genus yaitu Leognathus (7 spesies), Secutor (3 spesies), dan Gaza (2 spesies). Di antara ikan petek yang tertangkap, Leiognathus bindus mempunyai laju tangkap paling tinggi yaitu $12,53 \mathrm{~kg}$ per jam, dengan ukuran dominan antara FL 6,5 sampai dengan 7,0 cm, sedangkan Leiognathus splendens merupakan urutan ke-2 dengan laju tangkap 6,66 kg per jam, dengan ukuran dominan antara FL 10,0 sampai dengan 10,5 cm. Distribusi secara vertikal menunjukkan bahwa ikan petek, dominan tertangkap pada kedalaman perairan 21 sampai dengan $30 \mathrm{~m}$, yang berlaku untuk semua jenis atau spesies ikan petek (Leiognathidae). Sedangkan distribusi horisontal ikan petek, dominan tertangkap di sekitar perairan Nunukan dan Tarakan.
\end{abstract}

\section{KATA KUNCI: komposisi, distribusi, hasil tangkapan, ukuran, ikan petek, Selat Makassar}

\section{ABSTRACT: Distribution, catch, and size composition of pony fish (Leiognathidae) in the waters of Makassar Strait. By: Wedjatmiko, Tri Ernawati, and Sukarniaty}

Research on catch composition, distribution, and some biological aspects of pony fish was conducted in June to July, 2005 th using RV. Bawal Putih in the waters of East Kalimantan. Results show that the pony fish (Leiognathidae) provides the second largest component in the catch (17.43\%), after Ariidae (30.02\%). There were 3 genera of Leiognathidae i.e. Leiognathus (7 species), Secutor (3 species), and Gaza (2 species). Leioghnatus bindus was the highest catch rate within the Leioghnatidae group amoung to about $12.5 \mathrm{~kg}$ per $\mathrm{hr}$, with the dominant size of FL 6.5 to $7.0 \mathrm{~cm}$ group, followed by Leioghnatus splendens with the catch rate of $6.75 \mathrm{~kg}$ per hr and the size of 10.0 to $10.5 \mathrm{~cm}$. Based on depth distribution data it's likely that the pony fish group was dominantly in the depth range of 21 to $30 \mathrm{~m}$. Based on horizontal distribution data the pony fish group was dominantly in the East-Tarakan waters (1 ${ }^{\circ} 49^{\prime} \mathrm{N}-3^{\circ} 55^{\prime} \mathrm{N}$ dan $\left.117^{\circ} 53^{\prime} \mathrm{E}-118^{\circ} 31^{\prime} \mathrm{E}\right)$.

\section{KEYWORDS: $\quad$ composition, distribution, catch, size, ikan petek, Makassar Strait}

\section{PENDAHULUAN}

Ikan petek merupakan ikan demersal yang banyak tertangkap di perairan Laut Jawa (Badruddin, 1988). Pada tahun 19791 tahun sebelum dihapuskan trawl, ikan petek menempati urutan pertama dalam komposisi ikan demersal, yaitu 30\% dari laju tangkap ikan demersal (Dwiponggo \& Badruddin, 1980). Pada tahun 1986 ikan petek menempati urutan pertama dengan persentase yang lebih tinggi, yaitu $60 \%$ dari komposisi ikan demersal (Badruddin, 1988).

Ikan petek termasuk dalam famili Leiognathidae dan di Indonesia famili Leiognathidae terdapat 3 genera, yaitu Leiognathus, Secutor, dan Gazza (Pauly, 1977). Leiognathus terdiri atas 17 spesies, Secutor 2 spesies yaitu Secutor ruconius dan Secutor insidiator, sedangkan Gazza hanya 1 spesies yaitu Gazza minuta. Di Indonesia ditemukan 12 spesies ikan petek yang tersebar di perairan dangkal, atau kurang dari $40 \mathrm{~m}$ (Widodo, 1976). Parwati et al. (1988) mengatakan bahwa ikan petek yang dominan di Laut Jawa yang tertangkap oleh jaring trawl adalah jenis Leiognathus splendens.

Sejak 2 dekade terakhir ini sumber daya ikan di Selat Makassar telah mengalami tekanan penangkapan. Peningkatan eksploitasi ikan demersal dan udang di pantai timur Kalimantan dan pelagis kecil di bagian selatan Selat Makassar sudah berlangsung sejak lama. Eksploitasi udang dan ikan demersal cenderung meningkat dengan masuk bentuk penangkapan baru, yaitu mini traw/ dari kelas ukuran di bawah 30 GT yang berpangkalan di berbagai tempat dan beroperasi di daerah dekat pantai. Informasi dari berbagai kegiatan menunjukkan bahwa seluruh armada penangkapan telah mencapai jumlah lebih dari 1.000 unit yang berpangkalan di pantai timur Kalimantan dengan daerah

Kosrespondensi penulis: 
penangkapan telah menjangkau seluruh bagian perairan sampai dengan daerah perairan dangkal (untuk jenis mini trawl) dan terkonsentrasi di lokasi yang padat kelimpahan (Sadhotomo, 2004).

Ikan petek, sebagai penyeimbangan dalam sistem rantai makanan, karena Ikan petek berfungsi sebagai sumber makanan bagi ikan-ikan besar lain yang mempunyai nilai ekonomis lebih tinggi. Tulisan ini bertujuan untuk menyajikan data dan informasi mengenai sumber daya (komposisi dan distribusi) ikan petek di perairan Selat Malaka. Penelitian ini dilakukan dengan tujuan untuk mendapatkan data dan informasi mengenai sumber daya (komposisi dan distribusi) ikan petek di perairan Selat Makassar tersebut.

\section{BAHAN DAN METODE}

Penelitian ini dilakukan di perairan timur Kalimantan (Selat Makassar), pada tanggal 4 Juni sampai dengan 5 Juli 2005. Lokasi penelitian mulai dari perairan Nunukan yaitu perairan Selat Makassar paling utara, sampai dengan perairan Pulau Laut yaitu perairan Selat Makassar atau perairan timur Kalimantan paling selatan (Gambar 1).

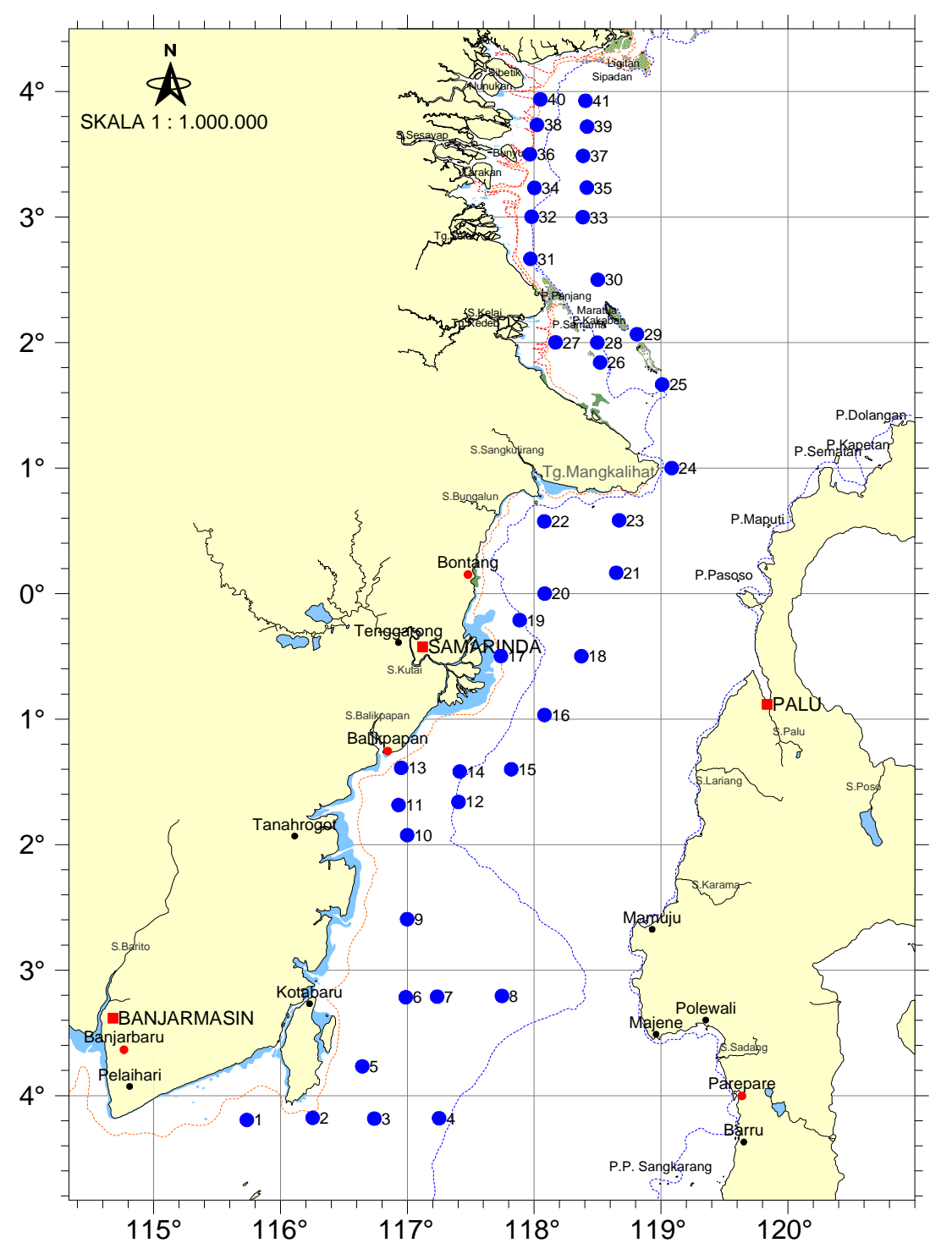

Gambar 1. Lokasi penelitian di perairan Selat Makassar.

Figure 1. Sampling location in Makassar Strait. 
Penelitian dilakukan menggunakan Kapal Riset Bawal Putih yang dilengkapi dengan alat tangkap Thailand trawl sebagai alat pengambilan contoh. Mengingat trawl adalah alat tangkap paling ideal untuk pengambilan contoh ikan demersal dan udang (Pauly, 1977). Rancang bangun alat tangkap trawl yang digunakan untuk pengambilan contoh, disajikan pada Lampiran 1. Stasiun penangkapan meliputi kedalaman 5 sampai dengan $60 \mathrm{~m}$ terdiri atas 32 stasiun.

Hasil pengambilan contoh berupa ikan dan udang disortir dan diidentifikasi menggunakan buku identifikasi ikan menurut Carpenter \& Niem, 1998a; 1998b; 1999; 2001a; 2001b; 2001c), Kailolla \& Tarp (1984); Allen (1999); de Bruin et al. (1994).

\section{HASIL DAN BAHASAN}

\section{Komposisi Jenis}

Dari hasil penelitian didapatkan komposisi jenis ikan 67 famili dengan 176 spesies, dan udang 5 famili dengan13 spesies. Komposisi hasil tangkapan dominan di perairan Selat Makassar berdasarkan pada famili ditampilkan pada Tabel 1, sedangkan komposisi hasil tangkapan ikan secara keseluruhan disajikan pada Lampiran 2.

Tabel 1. Komposisi hasil tangkapan ikan demersal di perairan Selat Makassar, tahun 2005 Table 1. Dominant catch composition of demersal fish in Makassar Straits, 2005

\begin{tabular}{clccc}
\hline No. & Famili/Family & $\begin{array}{c}\text { Jumlah hasil } \\
\text { tangkapan/Total } \\
\text { cacth }(\mathbf{k g})\end{array}$ & $\begin{array}{c}\text { Laju tangkap/Catch } \\
\text { rate } \mathbf{( k g} \text { per } \mathbf{~ h r})\end{array}$ & $\%$ \\
\hline 1. & Ariidae & $1.366,4$ & 42,7 & 30,0 \\
2. & Leiognathidae & 793,1 & 24,7 & 17,4 \\
3. & Rays & 385,9 & 12,0 & 8,4 \\
4. & Mullidae & 233,1 & 7,2 & 5,1 \\
5. & Nemipteridae & 184,9 & 5,7 & 4,0 \\
6. & Synodontidae & 136,2 & 4,2 & 2,9 \\
7. & Clupeidae & 119,9 & 3,7 & 2,6 \\
8. & Serranidae & 114,0 & 3,5 & 2,5 \\
9. & Gerreidae & 91,8 & 2,8 & 2,0 \\
10. & Sciaenidae & 75,2 & 2,3 & 1,6 \\
\hline
\end{tabular}

Hasil tangkapan ikan petek (Leiognathidae) menduduki urutan ke-2 setelah ikan manyung atau famili Ariidae. Berdasarkan pada sebaran atau hasil tangkapan per stasiun, ikan petek hampir dijumpai di setiap stasiun, sedangkan keberadaan ikan Ariidae tertangkap karena ada schooling yang besar di salah satu stasiun trawl, yaitu di wilayah perairan Berau (Tabel 2).
Berdasarkan pada Tabel 2 tersebut juga terlihat bahwa sebaran ikan petek (Leiognathidae), terdapat di semua wilayah perairan dengan laju tangkap yang hampir merata, kecuali di perairan Nunukan dengan laju tangkap paling tinggi $(11,24 \mathrm{~kg}$ per jam), dan perairan Tarakan dengan laju tangkap 6,38 kg per jam.

Tabel 2. Laju tangkap ikan petek (Leiognathidae) dan ikan manyung (Ariidae) di perairan Selat Makassar berdasarkan pada wilayah perairan

Table 2. $\quad$ Catch rate of Leiognathidae and Ariidae in sub area of Makassar Straits

\begin{tabular}{clccc}
\hline No. & $\begin{array}{c}\text { Wilayah perairan/ } \\
\text { Water area }\end{array}$ & Stasiun/Station & $\begin{array}{c}\text { Leiognathidae } \\
\text { (kg per jam) }\end{array}$ & $\begin{array}{c}\text { Ariidae } \\
\text { (kg per jam) }\end{array}$ \\
\hline 1. & Pulau Laut & $1,2,3,4$ & 2,2 & 0,1 \\
2. & Balikpapan & $5,6,7,8,9$ & 3,5 & 0,3 \\
3. & Berau & $10,11,12,13,14,15,16,17,18$ & 1,4 & 41,6 \\
4. & Tarakan & $19,20,21,22,23,24,25$ & 6,4 & 0,4 \\
5. & Nunukan & $26,27,28,29,30,31,32$ & 11,2 & 0,3 \\
\hline
\end{tabular}


Apabila dilihat lebih lanjut menunjukkan bahwa jenis ikan petek yang tertangkap di perairan Selat Makassar berjumlah 12 spesies. Spesies yang paling dominan adalah jenis Leiognathus bindus $50,6 \%$, ke-2 adalah Leiognathus splendens $26,9 \%$, dan yang ke-3 adalah Leiognathus leosiscus $9,3 \%$. Jenis ikan petek yang lain persentase relatif kecil, dan yang paling sedikit adalah spesies Gaza achlamys dengan persentase hanya 0,01\% (Tabel 3).

Menurut Widodo, (1976) ikan petek yang tertangkap di perairan Indonesia berjumlah 12 spesies yang tersebar di perairan dangkal, atau kurang dari $40 \mathrm{~m}$. Sedangkan ikan petek yang dominan tertangkap oleh jaring trawl di Laut Jawa adalah jenis Leiognathus splendens (Parwati et al., 1988). Sedangkan hasil penelitian ini yang dominan tertangkap di wilayah perairan Selat Makassar adalah Leiognathus bindus, sementara Leiognathus splendens menempati urutan ke-2. Hal ini, diduga kondisi di perairan Selat Makassar lebih cocok untuk habitat jenis $L$. bindus.

Tabel (3) juga menunjukkan bahwa hampir semua jenis ikan petek terdapat di perairan Selat Makassar. Ikan petek (Leiognathidae) di Indonesia, terdapat 3 genus, yaitu Leiognathus, Secutor dan Gazza. Leiognathus terdiri atas 17 spesies, Secutor ada 2 spesies yaitu Secutor ruconius dan Secutor insidiator, sedangkan Gazza hanya 1 spesies yaitu Gazza minuta (Pauly, 1977). Ikan petek hasil survei genera Leiognathus hanya terdapat 7 spesies (Leiognathus bindus, Leiognathus splendens, Leiognathus leusiscus, Leiognathus equulus, Leiognathus $K$. H., Leiognathus elongatus, dan Leiognathus smithursti), genus Secutor justru lebih banyak, yaitu 3 spesies (Secutor indicius, Secutor insidiator, dan Secutor ruconius), demikian juga dengan genus Gaza dijumpai 2 spesies, yaitu Gazza minuta dan Gaza achlamys.

Tabel 3. Komposisi hasil tangkapan ikan petek di perairan Selat Makassar

Table 3. Species composition and catch rate of pony fish in Makassar Straits

\begin{tabular}{clccc}
\hline No. & Spesies/Species & $\begin{array}{c}\text { Tangkapan total/ } \\
\text { Total cacth } \\
\mathbf{( k g )}\end{array}$ & $\begin{array}{c}\text { Laju tangkap/ } \\
\text { Catch rate } \\
\text { (kg per hr) }\end{array}$ & $\%$ \\
\hline 1. & Leiognathus bindus & 400,8 & 12,5 & 50,64 \\
2. & Leiognathus splendens & 213,2 & 6,6 & 26,93 \\
3. & Leiognathus leusiscus & 78,8 & 2,4 & 9,96 \\
4. & Leiognathus equulus & 29,2 & 0,9 & 3,69 \\
5. & Secutor indicius & 25,1 & 0,7 & 3,18 \\
6. & Gaza minuta & 18,7 & 0,5 & 2,37 \\
7. & Secutor insidiator & 14,8 & 0,4 & 1,88 \\
8. & Secutor ruconius & 7,2 & 0,2 & 0,91 \\
9. & Leiognathus K. H. & 2,7 & 0,1 & 0,34 \\
10. & Leiognathus elongatus & 0,5 & 0,02 & 0,06 \\
11. & Leiognathus smithursti & 0,2 & 0,01 & 0,02 \\
12. & Gaza achlamys & 0,1 & 0,005 & 0,01 \\
\hline & Jumlah/Total & $\mathbf{7 9 1 , 6 9}$ & $\mathbf{2 4 , 7 4}$ & $\mathbf{1 0 0 , 0 0}$ \\
\hline
\end{tabular}

\section{Komposisi Ukuran}

Salah satu aspek biologi ikan petek yang diamati di perairan Selat Makassar, adalah frekuensi panjang ikan (fork length). Leiognathus bindus merupakan salah satu spesies yang paling dominan tertangkap di perairan Selat Makassar, dengan kisaran panjang 3,5 sampai dengan $7,5 \mathrm{~cm}$, dengan frekuensi tertinggi pada ukuran FL 6,5 sampai dengan 7,0 cm (Gambar 2). Dari gambar tersebut tampak terdapat 2 modus, modus ke- 1 pada $4,25 \mathrm{~cm}$ dan modus ke-2 pada $6,75 \mathrm{~cm}$. Hal ini, menunjukkan $L$. bindus yang tertangkap di perairan Selat Makassar diduga terdapat 2 kelompok ukuran dari generasi yang berbeda. 


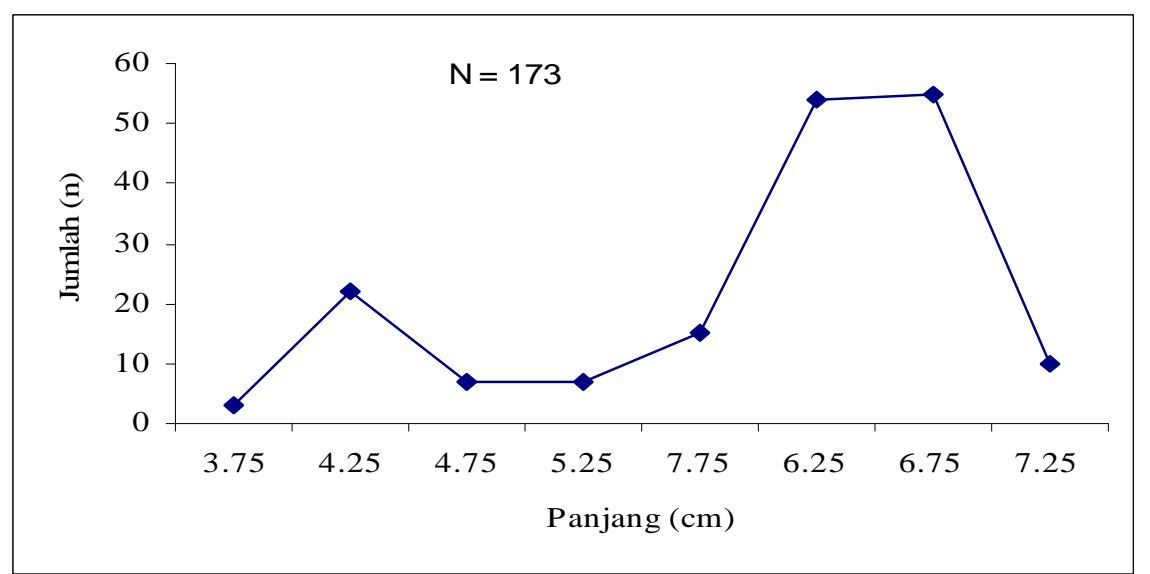

Gambar 2. Sebaran ukuran Leiognathus bindus di perairan Selat Makassar. Figure 2. Length distribution of Leiognathus bindus in Maccasar Strait.

Jenis ikan petek yang dominan ke-2 setelah Leiognathus bindus adalah Leiognathus splendens. Ukuran panjang ikan Leiognathus splendens yang tertangkap di perairan Selat Makassar lebih besar daripada Leiognathus bindus. Hasil pengukuran contoh 415 ekor menunjukkan bahwa, kisaran panjang ikan Leiognathus splendens antara FL 6,5 sampai dengan
$13,0 \mathrm{~cm}$, dengan frekuensi tertinggi ikan tertangkap pada ukuran 10,0 sampai dengan $10,5 \mathrm{~cm}$ (Gambar 3). Dari gambar tersebut tampak ada modus-modus yang diduga tumpang tindih satu sama lain, di mana yang sangat menonjol terjadi pada $9,25 \mathrm{~cm}$. Modus yang tumpang tindih diduga terjadi pada 7,$75 ; 9,25 ; 10,75$; dan 12,75 $\mathrm{cm}$.

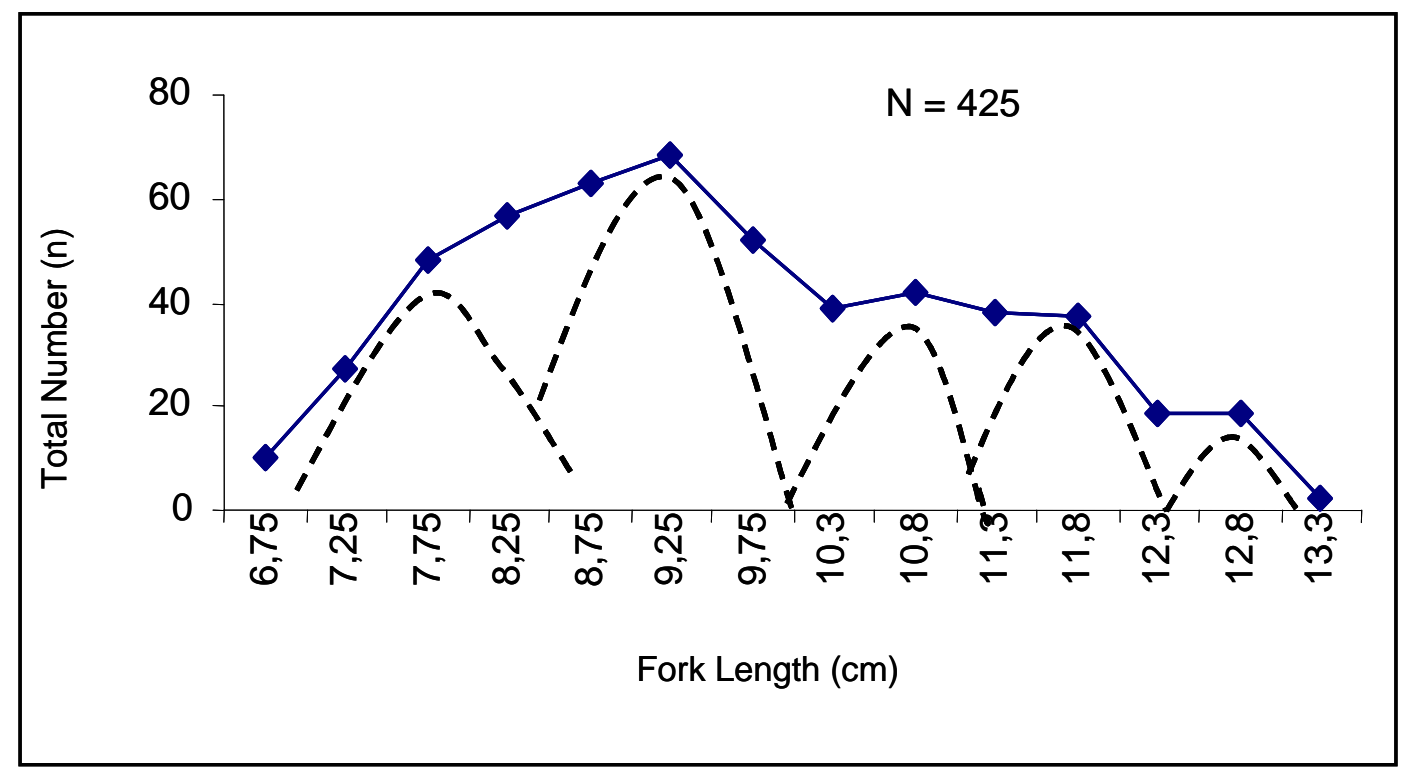

Gambar 3. Sebaran ukuran Leiognathus splendens di perairan Selat Makassar.

Figure 3. $\quad$ Length distribution of Leiognathus splendens in Maccasar Strait.

Di antara jenis ikan petek, yang mempunyai ukuran paling besar dibandingkan jenis ikan petek lain adalah Leiognathus equulus. Hasil pengukuran panjang ikan dengan jumlah contoh 80 ekor, diperoleh kisaran antara 9,0 sampai dengan $22,5 \mathrm{~cm}$. Berbeda dengan jenis petek yang lain, Gambar 4 tampak sejumlah modus yang sebagian tumpang tindih dari lain. Modus yang jelas antara lain 10,$25 ; 11,25 ; 12,25 ; 17,75 ; 15,75 ; 16,75$; 17,$75 ; 20,25$; dan 22, $75 \mathrm{~cm}$. 


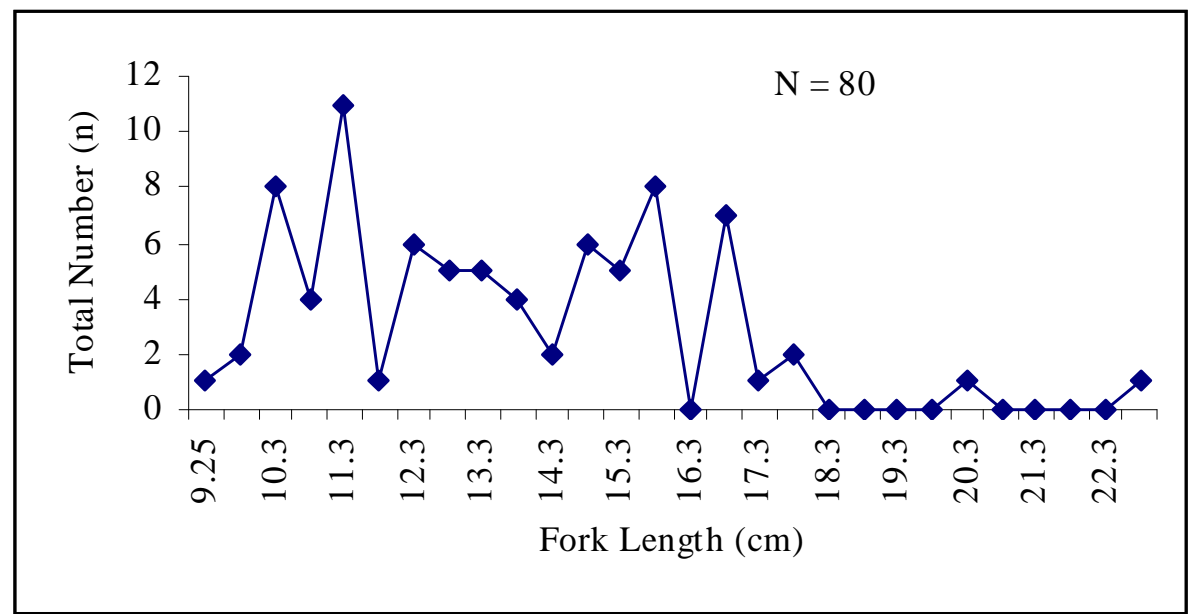

Gambar 4. Sebaran ukuran Leiognathus equluus di perairan Selat Makassar.

Figure 4. $\quad$ Length distribution of Leiognathus equluus in Makassar Strait.

\section{Penyebaran}

Dari data sebaran ikan petek di perairan Selat Makassar berdasarkan pada kisaran kedalaman 6 sampai dengan $68 \mathrm{~m}$, tampak semakin dalam perairan, maka densitas ikan petek semakin sedikit. Hal ini, sesuai dengan yang dikatakan oleh Widodo, (1976) bahwa ikan petek termasuk dalam famili Leiognathidae yang hidup tersebar di perairan dangkal. Di perairan Selat Makassar ikan petek banyak tertangkap pada kedalaman perairan 10 sampai dengan $40 \mathrm{~m}$, dan yang tertinggi hasil tangkapan adalah pada kedalaman perairan 21 sampai dengan $30 \mathrm{~m}$ (Tabel 4).

Tabel 4. Persentase laju tangkap ikan petek (\%) berdasarkan pada kedalaman perairan Table $4 . \quad$ Percentage of pony fish catch rate (\%) by water depth

\begin{tabular}{|c|c|c|c|c|c|c|c|}
\hline \multirow{2}{*}{ No. } & \multirow{2}{*}{ Spesies/Species } & \multicolumn{6}{|c|}{ Kedalaman/Depth } \\
\hline & & $<10 \mathrm{~m}$ & $11-20 \mathrm{~m}$ & $20-30 \mathrm{~m}$ & $30-40 \mathrm{~m}$ & $41-50 \mathrm{~m}$ & $>50 \mathrm{~m}$ \\
\hline 1. & L. bindus & 16,37 & 21,70 & 65,92 & 72,62 & 26,67 & - \\
\hline 2. & L. equulus & 1,08 & 3,20 & 0,62 & 11,38 & 13,33 & - \\
\hline 3. & Leiognathus K. H. & 0,93 & 0,90 & 0,06 & - & - & - \\
\hline 4. & L. leusiscus & 26,85 & 3,06 & 7,02 & 7,62 & - & 75,00 \\
\hline 5. & L. elongatus & 0,29 & - & 0,03 & - & - & - \\
\hline 6. & L. smithursti & - & - & 0,06 & - & - & - \\
\hline 7. & L. splendens & 39,63 & 54,24 & 21,50 & 5,96 & - & - \\
\hline 8. & Gaza minuta & 0,36 & 10,78 & - & 1,02 & 60,00 & 25,00 \\
\hline 9. & Gaza achlamys & - & - & 0,03 & - & - & - \\
\hline 10. & Secutor ruconius & 0,07 & 4,94 & 0,03 & 0,05 & - & - \\
\hline 11. & Secutor insidiator & 0,43 & - & 3,65 & 1,40 & - & - \\
\hline \multirow[t]{2}{*}{12.} & Secutor indicius & 14,36 & 1,18 & 1,09 & - & - & - \\
\hline & Jumlah/Total & 100,00 & 100,00 & 100,00 & 100,00 & 100,00 & 100,00 \\
\hline
\end{tabular}

Berdasarkan pada kedalaman, sebaran ikan petek berbeda-beda. Pada kedalaman $<10$ m dan 10 sampai dengan 20 m didominasi oleh Leioghnatus splendens, kedalaman 21 sampai dengan $30 \mathrm{~m}$ dan 31 sampai dengan 40 m didominasi oleh $L$. bindus, dan kedalaman 41 sampai dengan 50 m didominasi oleh Gazza minuta.
Demikian pula, dengan $L$. leusiscus tertangkap dalam jumlah yang dominan pada perairan yang lebih dalam (> $50 \mathrm{~m}$ ), sementara jenis ikan petek yang lain (Leiognathus bindus, Leiognathus splendens, Gaza minuta, dan Secutor indicius) hasil tangkapan cenderung menurun pada perairan yang lebih dalam (Gambar 5). 


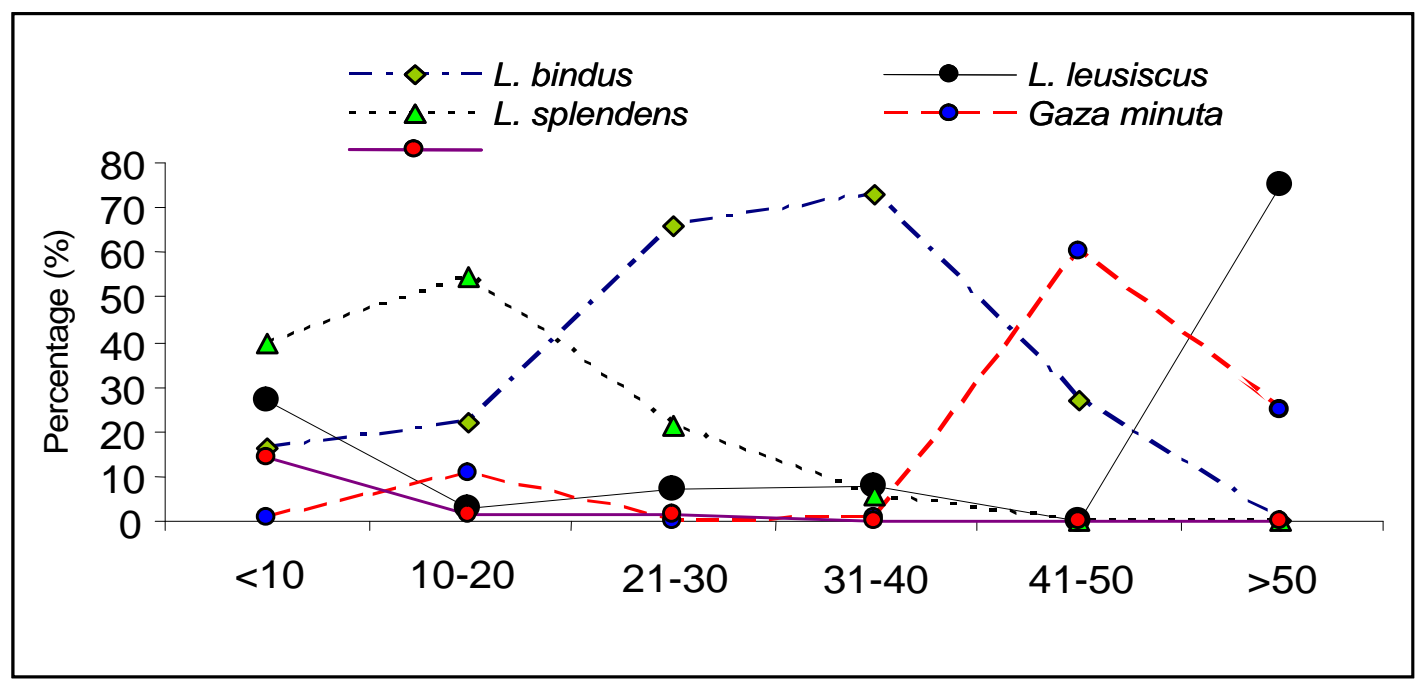

Gambar 5. Laju tangkap beberapa spesies ikan petek berdasarkan pada kedalaman. Figure 5. Catch rate of some pony fish in the Makassar Strait by water depth.

\section{KESIMPULAN}

Di perairan Selat Makassar terdapat 12 jenis ikan petek (Leiognathidae), dengan 3 genus yaitu genus Leognathus (7 spesies), Secutor (3 spesies), dan Gaza (2 spesies). Di antara ikan petek yang tertangkap, Leiognathus bindus mempunyai laju tangkap paling tinggi yaitu 12,53 $\mathrm{kg}$ per jam, dengan ukuran dominan antara FL 6,5 sampai dengan $7,0 \mathrm{~cm}$, sedangkan Leiognathus splendens merupakan urutan ke-2 dengan laju tangkap 6,66 kg per jam, dengan ukuran dominan antara $\mathrm{FL} 10,0$ sampai dengan $10,5 \mathrm{~cm}$. Distribusi secara vertikal menunjukan bahwa ikan petek, dominan tertangkap pada kedalaman perairan 21 sampai dengan $30 \mathrm{~m}$, yang berlaku untuk semua jenis ikan petek (Leiognathidae). Sedangkan distribusi horisontal ikan petek, dominan tertangkap di sekitar perairan Nunukan dan Tarakan.

\section{Persantunan \\ Hasil dari kegiatan riset: Stok Sumber Daya Perairan Selat Makassar T.A. 2005 di Balai Riset Perikanan Laut}

\section{DAFTAR PUSTAKA}

Allen, G. 1999. Marine fishes of South East Asia. Western Australian Museum. 1999.

Badruddin, M. 1988. Parameter stok dan potensi penangkapan ikan petek (Leiognathidae) di perairan pantai utara Jawa Tengah. Jurnal Penelitian Perikanan Laut. No.47 tahun 1988. Jakarta.
Carpenter, K. E. \& V. H. Niem. 1998a. The living Marine Reources of the Western Centrak Pacific. Vol.1. Seaweeds, Corals, Bivalvas, and Gastropods. Species Identification Guide for Fishery Purposes. Food and Agriculture Organization of the United Nations. Rome. 1998.

Carpenter, K. E. \& V. H. Niem. 1998b. The living marine reources of the western Centrak Pacific. Vol.2. Cephalopods, Crustaceans, Holothurians, and Sharks. FAO Species Identification Guide for Fishery Purposes. Food and Agriculture Organization of the United Nations. Rome. 1998.

Carpenter, K. E. \& V. H. Niem. 1999. The living marine reources of the western Centrak Pacific. Vol.3. Batoid fishes, Chimaeras, and Bony Fishes Part 1 (Elopidae to Linophrynidae). FAO Species Identification Guide for Fishery Purposes. Food and Agriculture Organization of the United Nations. Rome. 1999.

Carpenter, K. E. \& V. H. Niem. 2001a. The living marine reources of the western Centrak Pacific. Vol.4. Bony fishes part 2 (Mugillidae to Carangidae) FAO Species Identification Guide for Fishery Purposes. Food and Agriculture Organization of the United Nations. Rome. 1999.

Carpenter, K. E. \& V. H. Niem. 2001b. The living marine reources of the western Centrak Pacific. Vol.5. Bony fishes part 3 (Menidae to Pomacentridae) FAO Species Identification Guide for Fishery Purposes. Food and Agriculture Organization of the United Nations. Rome. 2001. 
Carpenter, K. E. \& V. H. Niem. 2001c. The living marine reources of the Western Central Pacific. Vol.6. Bony fishes part 4 (Laridae to Latimeriidae) Estuarine Crocodiles, Sea turtles, Sea snakes, and Marine mammals. FAO Species Identification Guide for Fishery Purposes. Food and Agriculture Organization of the United Nations. Rome. 2001.

Clyde F. E. Roper, Michael J. Sweeney, \& Cornelia E. Nauen. 1984. FAO species catalogue. Vol.3 Cephalopods of the world. United Nations Development Programme. Food and Agriculture Organization of the United Nations. Rome. 1984.

De Bruin G. H. P., Russell B. C., \& Bogusch A. 1994. FAO species identification guide for fishery purposes. The Marine Fishery Resources of Sri Lanka. Food and Agriculture Organization of the United Nations. Rome. 1994.

Dwiponggo, A. \& M. Badruddin. 1980. Result of the Java Sea inshore monitoring survey 1979 Contribution of demersal fish project. No.7, 1980. RMIF. Jakarta.
Kailola, P. J. \& Tarp T. G. 1984. Trawled fishes of Southern Indonesia and Northwestern Australia. Australian Development Assistance Bereau. Directorat General of Fisheries-Indonesia. German Agency for Technical Cooperation.

Parwati, M. D. \& D. Nugroho. 1988. Laju tangkap, sebaran, dan kelimpahan ikan petek (Leiognathus splendens Cuv., 1829) di pantai utara Jawa. Jurnal Penelitian Perikanan Laut. No.46 tahun 1988. Jakarta.

Pauly, D. 1977. The Leiognathus (teleostei) their species, stock, and fisheries in Indonesia, with notes on the biology of Leiognathus splendens. Marine Resources in Indonesia. 1977.

Sadhotomo, B. 2004. Riset bioekologi ikan pelagis dan demersal di perairan Laut Flores, Selat Makassar dan sekitarnya. Laporan Tahunan Internal. Balai Riset Perikanan Laut. Jakarta.

Widodo. 1976. A check list of the demersal species in the Java Sea. Special report No.1. Contribution of demersal fish project. MRIF. Jakarta.

Diterima tanggal: 21 April 2006

Diterima setelah perbaikan tanggal: 21 Juli 2006

Disetujui terbit tanggal: 21 Juli 2006 